\title{
Participação e desenvolvimento em assentamentos humanos
}

\section{Introdução}

O último trimestre do ano de 1999 nos reservou uma experiência mais que interessante. Entre os meses de outubro e dezembro, tivemos a oportunidade de participar, como parte integrante de um consórcio de instituições capacitadoras (Fundação João Pinheiro - FJP, Fundação Getúlio Vargas - FGV e Instituto Brasileiro de Administração para o Desenvolvimento - IBRAD) do Programa Comunidade Ativa (PCA).

Tendo como principal objetivo introduzir, nas comunidades selecionadas, uma nova filosofia de desenvolvimento, o Desenvolvimento Local Integrado e Sustentável (DLIS), o PCA propunha, como uma de suas intervenções, uma iniciativa de capacitação das lideranças locais, preparando-as para assumir a dianteira desse processo.

Basicamente, essa iniciativa de capacitação organizava-se em torno de um esforço coletivo voltado para a elaboração (pelas lideranças locais) de um Plano de Desenvolvimento Local Integrado e Sustentável (PDLIS), ocasião em que seriam discutidos conteúdos e conceitos que fundamentam tal filosofia de desenvolvimento, bem como seriam instigados processos de participação política nessas comunidades.

Como responsáveis pela coordenação das ações de capacitação do IBRAD ${ }^{1}$, pudemos acompanhar o desenvolvimento dos trabalhos em 13 localidades dos estados do Mato Grosso do Sul: Angélica, Bataguassu, Nioaque, Porto Murtinho e Sete Quedas; de Goiás: Padre Bernardo, Novo Gama, Planaltina de Goiás, Santo Antônio do Descoberto e Águas Lindas; e do Distrito Federal (DF): Brazlândia, Paranoá e Riacho Fundo.

Paulo Henrique Lustosa é administrador de empresas, mestrando em Política Social pela UnB e presidente do IBRAD 
Mais que uma simples iniciativa de capacitação, as ações que viemos desenvolvendo nesse período nos permitiu, por um lado, uma visão totalmente renovada da questão da participação política das comunidades e, por outro, subsidiou-nos com informações e observações sobre a complexidade do processo político e das suas relações com o desenvolvimento local.

Uma observação mais atenta nos permitiu extrair, de todo esse rico processo, uma série de considerações sobre particularidades do trabalho que estivemos desenvolvendo durante esse período que, somadas às informações produzidas pelos próprios Fóruns de Desenvolvimento Local (FDL) e às contribuições dos demais capacitadores da equipe do IBRAD, levaram à produção deste documento.

Desde o início, pareceu-nos pertinente buscar, na experiênciapiloto que era patrocinada pelo Ministério do Planejamento, Orçamento e Gestão e pelo Comunidade Solidária, características e conclusões mais genéricas que contribuíssem, científica e metodologicamente, para a intensificação das discussões em torno de temas tão palpitantes e atuais quanto são: participação, auto-determinação local e sustentabilidade do desenvolvimento.

A possibilidade que nos foi dada de trabalhar com oito localidades (as cinco de Goiás e as três do Distrito Federal) que, embora reconhecendo suas peculiaridades, fossem sujeitas a variáveis exógenas bastante comparáveis, permitiu um elevado grau de comparabilidade entre os resultados obtidos e a produção das conclusões e observações gerais que trazem este documento.

Daí para começarmos a trabalhar nas relações entre participação, desenvolvimento local e comunidades que haviam sido criadas recentemente ou que em um curto período foram objeto de um acelerado processo de crescimento demográfico, foi apenas uma questão de tempo.

Para melhor estruturar esta discussão, o trabalho foi organizado em oito etapas que tentam responder às seguintes perguntas: até que ponto o fato de serem assentamentos recentes afetou o processo de participação política e, conseqüentemente, a discussão sobre o DLIS nessas localidades? E, sendo possível constatar algum efeito, existiriam padrões e considerações gerais que pudessem ser extraídas dessa experiência?

A primeira etapa, vai trabalhar a definição de assentamento humano recente na perspectiva deste documento, identificando os aspectos que garantem algum grau de similaridade entre as diversas realidades observadas com base no prazo demandado para a formação das comunidades analisadas.

Já na segunda, traça-se um rápido histórico de cada uma das comunidades, enquadrando-as, naquilo que possível, à definição de 
assentamento humano recente e apontando os aspectos e as características que destoam do modelo proposto.

Pareceu-nos pouco adequado apresentar nossas observações sem uma menção direta ao processo de capacitação, à metodologia adotada pelo IBRAD nessas localidades e, por consequiência, como essa opção metodológica pode, ou poderia, afetar o observado. Esta é a terceira etapa.

A quarta etapa, por sua vez, discute a questão da relação entre a sensação de pertencer a uma determinada localidade, e como essa sensação ou a sua falta podem afetar os processos de construção de um movimento de promoção do desenvolvimento que se funda no comprometimento e na participação da comunidade.

A quinta etapa vai discutir a relação entre os assentamentos recentes e o também recente processo de formação de lideranças; como isto afeta sua representatividade e, eventualmente, o próprio processo de participação na construção de um modelo de DLIS.

$\mathrm{Na}$ sexta etapa, tratamos das particularidades observadas nessas localidades no que tange ao relacionamento entre a área urbana e a área rural dos municípios. Embora, não diretamente conectada à questão da participação política, essa questão tem forte repercussão sobre a perspectiva do "desenvolvimento integrado".

A sétima etapa vai tentar articular dois vetores basilares do planejamento do desenvolvimento local na perspectiva do DLIS: participação e economia. O objetivo é tentar consolidar e demonstrar os efeitos das especificidades descritas para os assentamentos humanos recentes sobre a participação comunitária e, sem tanto detalhar, as dificuldades para a metodologia do PCA decorrentes das particularidades econômicas dessas localidades.

A oitava e última etapa consolida um breve conjunto de idéias sobre como, na nossa avaliação, deve se comportar o Estado quando da implementação de processos assemelhados, ou seja, de planejamento e gestão do desenvolvimento com participação em assentamentos humanos recentes.

\section{Assentamentos humanos recentes}

Ao se empreender o processo de capacitação das lideranças locais, preconizado no PCA, foi possível identificar nos municípios contemplados no estado de Goiás e nas administrações regionais do DF, um conjunto de características que conformavam um perfil, razoavelmente, comum a todas aquelas localidades.

Esse perfil geral não sacrifica as especificidades locais, uma vez que, o que se observa de uma localidade para a outra é a intensidade e/ou 
a freqüência com que elas se manifestam, entretanto, permitem um conceito genérico que neste ponto se tentará delinear.

Uma primeira forma de dar maior clareza ao conceito é a análise do mesmo com base nos termos que o adjetivam. Assim, é prudente explicar qual a interpretação que foi dada para cada um dos termos que compõem o conceito. Mais prudente ainda é reconhecer que tais interpretações não se pretendem definitivas, pelo contrário, são um primeiro esforço de explicação de uma realidade observada. Assim, temos:

- assentamentos - mais que aglomerados ou cidades. Como vai ser observado, praticamente todas as localidades experimentaram processos de ocupação organizados e/ou estimulados pelo Estado, em especial, pelo Governo do Distrito Federal (GDF), fruto das políticas habitacionais e das ações de erradicação de invasões ${ }^{2}$ e remoção de favelas;

- humanos — não como uma mera afirmação de que são seres humanos que habitam tais localidades, o que eventualmente parece ser necessário lembrar a alguns, mas para fugir da tradicional classificação de assentamentos urbanos. Isto porque uma das características que aqui se discute é, precisamente, o conflito entre o urbano e o rural decorrente desses processos de assentamento; e

- recentes - não necessariamente em função da data de criação do município e/ou do surgimento dos seus primeiros núcleos urbanos, mas porque experimentaram nos últimos anos um acelerado processo de crescimento demográfico.

Além disso, em decorrência de suas posições geográficas, todas as localidades, sem se falar nas Regiões Administrativas (RA) têm seu surgimento/desenvolvimento intimamente ligado ao surgimento e crescimento de Brasília e o conseqüente aumento dos fluxos migratórios para a região, provindos de todos os rincões brasileiros.

Buscando uma definição mais precisa, é possível recorrer ao Mapa dos Processos Formadores da Dinâmica Territorial do Distrito Federal de 1998, elaborado por Rafael Araújo. Esse estudo, que tem por objetivo "revelar as novas relações na organização espacial, a urbana, sobretudo, que se configuram no Distrito Federal", aponta para a existência de dois pólos dinamizadores da urbanização no DF (o Plano Piloto como pólo centralizador e o conjunto Taguatinga, Ceilândia e Samambaia, como pólo complementar) identificando, ainda, como outros dois componentes fundamentais da dinâmica de urbanização do DF o anel semi-radial envolvendo o Plano Piloto e o conjunto de localidades de Goiás, fronteiriças ao DF, caracterizadas pela disseminação de loteamentos populares.

Com relação ao presente estudo, é interessante destacar que das oito localidades aqui analisadas, embora as do DF não apareçam com maior destaque $^{3}$, todas as localidades de Goiás, exceto Padre Bernardo, são classificadas como "localidade fronteiriça ao Distrito Federal com significativa 
expansão de parcelamentos populares"4, que pode ser considerada como mais um traço de similaridade entre as localidades estudadas.

Essa outra peculiaridade implica que essas localidades, em sua enorme maioria, reúnem pessoas oriundas de todo o Brasil e, em função disso, culturas e histórias radicalmente diferenciadas, o que tende a tornar o processo de organização da comunidade mais desafiante e complexo. Isso porque para fins dessa discussão, podemos recorrer a Jara (1999) e considerar que:

"Quando falamos de cultura estamos falando da forma de vida de um povo, sua personalidade, os conhecimentos, as crenças, idéias coletivas, costumes; a maneira como as pessoas de um determinado agrupamento social, inseridas num determinado meio ambiente, se organizam para conseguir seus objetivos, após uma cadeia de ensaios e erros. O social é tudo aquilo que se refere à vida coletiva organizada, aos grupos que compõem uma determinada sociedade e a malha de relacionamentos que se estabelecem entre eles."

Por sua vez, e ainda como conseqüência da proximidade com Brasília, a maior parte dessas cidades foram criadas para serem ou se converterem em cidades-dormitórios ou núcleos-dormitórios ${ }^{5}$ com suas repercussões em termos de organização dos atores sociais e, principalmente, como restrição adicional na identificação de potencialidades econômicas e produtivas, capazes de garantir a sustentabilidade econômica do processo de desenvolvimento que se pretende deslanchar.

Esse conjunto de características, comuns em maior ou menor intensidade às localidades ora analisadas, gera consequiências sobre o processo de indução ao desenvolvimento local integrado e sustentável preconizado pelo PCA e, acreditamos, para qualquer esforço de organização proposto para a sociedade.

\section{Um breve histórico das localidades estudadas}

Não nos parece possível discutir a história das localidades, objeto desse trabalho, sem iniciar uma breve compreensão do papel histórico da criação de Brasília sobre elas e o seu desenvolvimento.

Em primeiro lugar, das oito localidades analisadas, apenas três delas (Padre Bernardo, Brazlândia e Santo Antônio do Descoberto) existiam antes do início da construção de Brasília (é bem verdade que Planaltina de Goiás tem uma história que antecede esse processo) e mesmo assim a criação de Brasília alterou de forma significativa suas perspectivas e tendências de desenvolvimento. 
Em segundo lugar, as três localidades do Distrito Federal (Brazlândia, Paranoá e Riacho Fundo) são locais, mas não são Unidades da Federação (UF). São RA do Distrito Federal, isto é, são unidades administrativas do GDF. São ou foram, principalmente, produtos das estratégias do governo local para acomodar o rápido crescimento populacional do DF que o Estado não pôde, ou não quis, acomodar dentro da expansão urbana do Plano Piloto.

Assim, é de suma importância para o conhecimento do processo de expansão / criação desses assentamentos humanos recentes compreender Brasília como um empreedimento urbano orientado para acomodar o centro político e administrativo do país e que "no projeto original da cidade / inexistiam programas de habitação para a população não vinculada direta ou indiretamente à administração pública" (Iwakami, 1998).

A resposta encontrada pelo Estado para a solução dos problemas de ocupação irregular e precária de áreas do Plano Piloto (as chamadas invasões) sempre se orientou para a remoção das invasões e a criação das cidades-satélites que, distando entre 17 e $60 \mathrm{~km}$ do Plano, recebiam as famílias removidas, na base de um lote para cada família transferida.

Esse procedimento adotado com intensidade pelo GDF, durante toda a década de 60, sofre um arrefecimento durante os anos 70 e $80 \mathrm{em}$ função da sensível redução nos investimentos estatais em políticas habitacionais para as populações mais carentes.

Assim, o projeto de implantação de Samambaia ${ }^{6}$,que em 1981 já constava dos mapas de expansão como a futura cidade do Departamento Administrativo do Serviço Público (DASP), com capacidade para 60 mil habitantes, foi freqüentemente adiado. Entre 1981 e 1984 nenhuma habitação foi construída. Em fins de outubro de 1984, foram licitados os primeiros lotes e, apenas em março de 1985 , foram iniciadas as primeiras obras de infra-estrutura.

Basicamente, são duas as principais respostas à redução dos investimentos do Estado nessa área. De um lado, iniciam-se extensos loteamentos no município de Luziânia, no estado de Goiás, e em outros municípios circunvizinhos. De outro, observou-se um crescimento constante da população dentro dos limites do DF, residindo em fundos de lotes, cortiços e invasões cada vez mais numerosas.

No final dos anos 80, há uma mudança na política do GDF para habitações populares, com a retomada das ações de remoção e assentamento de invasões, e com a distribuição de lotes populares, que tem em Samambaia seu principal símbolo. Citando Paviani (1998):

"É interessante demarcar a diferença de estilo perceptível nos governos de José Aparecido de Oliveira (1985/1987) e Joaquim Roriz (1988/1990) quanto à Samambaia: na etapa do primeiro, o povoamento é lento e, ao final, propõe alteração do uso da terra 
(com vistas à implantação de indústrias); na etapa Roriz (cujo nome

para governador foi aprovado em 15 de setembro de 1988), o assentamento de favelados transferidos do Plano Piloto é acelerado, enquanto os moradores iniciais clamam por mais infra-estrutura, prevendo a deterioração dos serviços com a chegada (malvista) dos favelados."

Esse processo, entretanto, não se restringe apenas à Samambaia. Com a sua eleição para o período seguinte (1990/1994) o Governador Roriz mantém sua política de erradicação de invasões e de distribuição de lotes semi-urbanizados em cidades-satélites existentes ou criadas para este fim.

Enquanto isso, os loteamentos nos municípios limítrofes com o Distrito Federal, estados de Goiás e Minas Gerais, crescem em um ritmo assustador a ponto de, por exemplo, apenas o município de Luziânia ter sido desmembrado no curto período de 1990/1996 em três outros: Novo Gama, Valparaízo de Goiás e Cidade Ocidental.

É dentro deste contexto mais amplo e complexo que passamos a observar, com um pouco mais de detalhe, a história das oito localidades, objeto desse estudo, com especial atenção para os aspectos que vão conformá-las (excetuando-se o município de Padre Bernardo/GO) em assentamentos humanos recentes.

\section{Águas Lindas - GO}

Inicialmente denominado Parque da Barragem, por estar localizado às margens da barragem do Rio Descoberto, o município de Águas Lindas era um distrito do município de Santo Antônio do Descoberto.

Localizado às margens da BR 070 entre os $\mathrm{km} 21$ e 31, ligando Brasília a Corumbá, Cocalzinho, Edilândia e Girassol e distando apenas $50 \mathrm{~km}$ do Plano Piloto e $20 \mathrm{~km}$ do pólo complementar (Taguatinga, Ceilândia e Samambaia), o munincípio passou a atrair um grande número de moradores provindos de diversas localidades, especialmente Goiás e Tocantins.

Seu crescimento levou à emancipação do distrito, que tornou-se município no dia 12 de outubro de 1995, passando a se chamar Águas Lindas de Goiás. No dia 3 de outubro de 1996, foi realizada a primeira eleição na cidade.

O município destaca-se como um dos principais exemplos do acelerado crescimento das localidades fronteiriças ao DF, mormente em função dos loteamentos regulares ou irregulares. Atualmente, Águas Lindas possui mais de 100 loteamentos.

Esse crescimento apresenta-se de forma ainda mais contundente nos dados relativos à população local e seu crescimento. Se no início da 
década de 90 o Parque da Barragem era um distrito com pouco mais de 5.000 habitantes, no ano de 1996, o número de habitantes já superava as 40.000 pessoas $^{7}$.

Dois anos depois, quando da realização do censo da saúde pública, já foram identificados cerca de 130.000 habitantes no município. Atualmente, em função do acelerado crescimento e do recrudescimento do fluxo migratório, as estimativas da prefeitura já apontam para uma população de mais de 150.000 habitantes, sendo que $80 \%$ destes estão na zona urbana do município.

\section{Brazlândia — DF}

O povoado de Brazlândia surgiu na década de 30, nas imediações da fazenda de propriedade da família Braz. Até o final dos anos 50, o vilarejo pouco se modificou sendo, basicamente, uma rua com poucas casas de adobe e telha colonial, e alguns casebres cobertos de palha, tendo como foco de consolidação urbana uma pequena capela e algumas casas comerciais de pequeno porte.

Com a construção de Brasília, a vida na cidade se modificou com a chegada de centenas de agricultores que foram assentados no Núcleo Alexandre Gusmão, preparando-a para se tornar um dos centros de abastecimento da nova capital. Em 1969, Brazlândia obteve sua condição de cidade-satélite do Distrito Federal.

Localizada a 50km a noroeste do Plano Piloto, Brazlândia é o núcleo urbano da RA IV do Distrito Federal e possui, atualmente, 62.000 habitantes. Entretanto, mais que simplesmente observar o tamanho da população da RA, é interessante observar o ritmo de sua evolução e, em função disto, sua caracterização como assentamento humano recente.

Em 1970, um ano após obter sua condição de cidade-satélite, Brazlândia possuía uma população de $9.592^{8}$ habitantes. Em 1980, a população havia mais que dobrado, superando os 22.500 habitantes, ritmo de crescimento que praticamente se repetiu para a década seguinte. De sorte que, em 1991, a população já era de 41.119 pessoas e, em 1995, chegava perto dos 45.000 habitantes.

Considerando a estimativa de aproximadamente 62 mil habitantes para 1999 e os números para 1991, observamos que nessa década a população de Brazlândia aumentou em mais de 50\%, um incremento considerável mesmo para os padrões do $\mathrm{DF}^{9}$.

\section{Novo Gama - GO}

Distante 40km de Brasília e com sua sede distando apenas 500 metros da cidade-satélite de Santa Maria no DF, o município de Novo 
Gama foi criado em 19 de julho de 1995, e o primeiro prefeito foi eleito em 1996, tomando posse em 1o de janeiro de 1997.

Desmembrado do município goiano de Luziânia, do qual até 1995 era distrito, o município é fruto desse exacerbado processo de crescimento demográfico do DF e da expulsão de um sem-número de pessoas para as suas fronteiras. Segundo informações da Secretaria Municipal de Viação, Obras e Agricultura, existem atualmente no município dez loteamentos regulares e três grandes favelas.

De acordo com levantamentos do IBGE, logo após a sua emancipação em 1996, o município contava com 64.416 habitantes. Entretanto, em função do fluxo migratório acelerado, em julho de 1999, foi feita nova estimativa da população do Novo Gama pelo instituto, oficializando sua população em 71.155, assim distribuída: 57.635 pessoas em sua área urbana e as outras 13.520 habitando a área rural.

\section{Padre Bernardo - GO}

O município de Padre Bernardo é, dentre as oito localidades analisadas, a única que não pode ser enquadrada no perfil de assentamento humano recente proposto nesse artigo, não apenas pelo fato de sua história remontar ao início da década de 30 (outros municípios aqui analisados também apresentam essa característica) mas, principalmente, em função de ele não ter experimentado o processo de ocupação e crescimento demográfico vivido pelos demais.

A história do município inicia-se com a movimentação dos romeiros provenientes das mais diversas partes da região do Vão dos Angicos que passaram a fazer romarias dedicadas ao divino Espírito Santo. Entretanto, o arraial de Barro Alto, que deu origem ao município, só veio a ser fundado em 1951, por Rosa Fernandes Carvalho e pelo Professor José Monteiro de Lima.

Em 1955, o povoado passou a adotar o nome de Padre Bernardo, em homenagem ao vigário Bernardo Stockler que atuava naquela região e que ali morreu e foi sepultado. Em 1956, a população local era de 225 pessoas, e a sua economia baseava-se, principalmente, na pecuária e na agricultura familiar.

Em 1960, quando da fundação de Brasília, o então distrito de Padre Bernardo do município de Luziânia, contava com uma população de 4.637 habitantes, evidenciando um rápido crescimento demográfico nesse período. No ano de 1964, foi instalado o município de Padre Bernardo e indicado o seu primeiro prefeito.

Distando 104km de Brasília e 65km de Brazlândia, o município de Padre Bernardo possuía, de acordo com a contagem da população de 1996 pelo IBGE, 16.879 habitantes. Atualmente, estima-se uma população 
de aproximadamente 17.000 pessoas, mostrando uma certa estabilidade no ritmo de crescimento.

Na verdade, se observado o crescimento populacional do município, veremos que é principalmente nesse ponto que ele se diferencia das demais localidades aqui analisadas. Enquanto em todas as outras sete localidades o período 1980/2000 foi de assustador crescimento, demográfico, em Padre Bernardo, a taxa de crescimento que na década $1970 / 1980$ tinha superado os $6 \%$ ao ano, entre 1980/1991, ficou negativa e, no período 1991/1996, ficou em menos de $1 \%$ ao ano, indicando uma tendência ao êxodo por parte da população local.

Como o município de Padre Bernardo se diferencia das demais localidades nesse ponto e em outros que posteriormente discutiremos com maior detalhe, ele não pode ser considerado assentamento humano recente, de modo que servirá de contraponto com as demais localidades.

\section{Paranoá - DF}

A cidade-satélite do Paranoá está localizada ao norte de Brasília, às margens do lago que lhe deu nome. Sua ocupação iniciou-se no começo da construção da barragem do Paranoá quando chegaram os primeiros trabalhadores da construção civil, os chamados candangos, atendendo aos apelos de JK, com a finalidade de tocarem as obras de construção da nova Capital Federal.

Por ter sido formada em função do acampamento da obra da barragem, a Vila Paranoá sempre contou com um número reduzido de habitantes, sendo que só a partir da década de 70 esse quadro começa a se alterar, principalmente, em função de outros fatores, tais como a remoção dos moradores da Vila do Instituto de Assistência e Previdência dos Industriários (IAPI) para a Ceilândia ${ }^{10}$.

Mesmo assim, os dados relativos à população local mostram que só a partir do início dos anos 80 (em sintonia com o que ocorria no restante do Distrito Federal) é que a população da Vila Paranoá começa a experimentar crescimentos significativos. Segundo levantamentos de Iwakami (1998), se, em 1969, a população local era de cerca de 1.000 habitantes e, em 1980, esse número ainda estava em pouco mais de 5.000 pessoas, em 1987, a população ali residente já superava as 36.000 pessoas.

Até então, o assentamento da Vila Paranoá era irregular e tolerado pelo Poder Público como um fato inevitável. A fixação definitiva da Vila Paranoá só veio a ocorrer 20 anos depois, no final do governo Aparecido, após amplo processo de mobilização de seus moradores ${ }^{11}$. O Decreto 12.055 de 14/12/89, editado pelo GDF, consolidou esta luta.

Após a regularização da cidade e da criação da RA do Paranoá, a cidade continuou experimentando um rápido processo de expansão de sua população e de sua área urbana. Atualmente, o Paranoá possui uma 
população de aproximadamente 60 mil pessoas e tem sido afetada por sérios problemas, como: desemprego, baixo nível de instrução da população e elevados índices de violência.

Esse crescimento pode ser justificado, entre outras coisas, pela sua localização privilegiada, uma vez que o Paranoá dista do Plano Piloto apenas $20 \mathrm{~km}$, situando-se entre os bairros Lago Sul e Lago Norte ${ }^{12}$, estando interligado a outros centros urbanos do DF.

\section{Planaltina de Goiás - GO}

Localizada a 54km de Brasília, Planaltina de Goiás (também chamada de Brasilinha) que assistiu a expedições de bandeirantes paulistas à procura de ouro, transformou-se em distrito de Formosa/GO em 1859, tornando-se município pelo Decreto 52 de 19 de março de 1891.

Em 1955, parte de seu território foi "declarado de utilidade pública e conveniência ao interesse social" em função de ser área destinada à localização da nova capital e, ainda no mesmo ano, a área delimitada no decreto foi desapropriada pelo Governo Federal. Em 1958, foi desmembrada parte da área do município de Planaltina, inclusive sua sede que converteu-se na cidade-satélite de Planaltina/DF, para a formação do Distrito Federal.

A partir de então, o município teve sua sede transferida entre distritos e fazendas até que, no ano de 1970, foi estabelecida no local onde se encontra atualmente. Nesse sentido, como primeira especificidade do município, temos uma localidade que, embora centenária, é um assentamento humano iniciado apenas nos anos 70 .

Segundo o estudo de contagem da população realizado pelo IBGE, em 1996, o município possuía uma população de 58.576 habitantes, sendo que destes, 54.909, ou seja, 92\% habitavam a sua área urbana. Eram 29.238 homens e 29.338 mulheres, em sua maioria jovens.

Do ponto de vista do crescimento demográfico, segundo levantamentos realizados pelo SEBRAE/GO ${ }^{13}$, a população local que, em 1970, era de 9.032 pessoas, chegou ao ano de 1980 com 16.469 habitantes, representando um crescimento médio de quase $7 \%$ ao ano. Em 1991, a população já superava os 40.000 habitantes, e o crescimento médio anual já se aproximava dos $8,5 \%$.

Essa taxa de crescimento tem-se mantido elevada (no período 1991/ 1996 superou os 7\% ao ano, em média) principalmente, em função dos fluxos migratórios. Ainda conforme estudo do SEBRAE, a população de migrantes é formada majoritariamente por nordestinos e reside em Planaltina há menos de cinco anos.

\section{Riacho Fundo - DF}

A cidade-satélite do Riacho Fundo é fruto da decisão do GDF de erradicar uma invasão no Setor de Indústrias e Abastecimento (SIA) que 
em, 13 de março de 1990, implicou a remoção e o assentamento de 562 famílias na Quadra 1 do Riacho Fundo.

Historicamente, poderíamos considerar que a origem da localidade foi a Granja Riacho Fundo, criada logo após a inauguração de Brasília, cuja sede foi transformada em 1990 no Instituto de Saúde Mental. Dentro da política de erradicação das invasões do GDF, o governo intensificou os assentamentos com a transferência dos moradores do bairro Telebrasília e de outras localidades, resultando no núcleo urbano do Riacho Fundo.

Em 1993, o núcleo urbano foi transformado em Região Administrativa (RA XVII) e, no ano seguinte, foi aprovado o parcelamento do que viria a se chamar Riacho Fundo II, com a capacidade para assentar mais 17.000 pessoas.

Atualmente, a RA está organizada em três setores: Telebrasília, que abriga os moradores vindos da antiga invasão que recebia esse nome; Riacho Fundo I, mais antigo e com melhor infra-estrutura; e Riacho Fundo II, recentemente assentado. Além disso, a localidade possui uma extensa área rural que incorpora os Conglomerados Agrourbanos de Brasília I e II (CAUB I e II), que têm sua origem em um projeto para populações rurais de baixa renda iniciado em 1982.

Neste curto período, entre 1990 e 1999, a localidade viu sua população crescer rapidamente, saindo das 562 famílias do primeiro assentamento para alcançar, em 1997, um total de 22.050 habitantes. Trabalhos mais recentes, realizados pelo IBGE, estimaram a população da RA XVII em 38 mil habitantes, sendo que desse total $95 \%$ residem na sua área urbana.

Dos habitantes do Riacho Fundo, 43,9\% são nascidos no DF, os mineiros $(10,8 \%)$ formam a segunda população, seguidos pelos goianos $(7,7 \%)$, piauienses $(6,1 \%)$, baianos $(5,6 \%)$ e cearenses $(4,7 \%)$. Também é importante notar que a maioria dos moradores, mais de $52 \%$, mora na localidade há menos de 15 anos.

\section{Santo Antônio do Descoberto - GO}

Santo Antônio do Descoberto é uma localidade que tem suas origens em meados de 1746 com a vinda do bandeirante Antônio de Azevedo, e outros oriundos de Luziânia, para desbravar a região.

Em 1757, o major José Pereira Lisboa, ao abrir frentes de serviço às margens do Ribeirão Despenhado, encontrou grande quantidade de ouro, de modo que o ribeirão passou a ser chamado de Descoberto. No ano seguinte, Lisboa mandou construir uma capela dedicada a Santo Antônio, tornando-se freqüente a romaria dedicada ao santo no mês de junho. O povoado crescia em torno da igreja, embora em um ritmo bastante lento.

Em 1963, Santo Antônio foi elevado à categoria de distrito de Luziânia. Somente a partir da inauguração de Brasília, mais especificamente a partir 
da década de 70, a cidade experimenta uma aceleração no seu crescimento populacional, tendo sido emancipada no dia 14 de maio de 1982.

De acordo com estimativas do IBGE, a população de Santo Antônio do Descoberto, em 1999, era de 67.024 pessoas, contra uma população estimada para 1997 de 53.914 pessoas. Apesar, ou em decorrência, do espetacular crescimento da cidade, existem muitas controvérsias quanto ao tamanho da população local.

Por exemplo, as últimas estimativas realizadas pela Prefeitura Municipal, baseadas no Cadastro Imobiliário, indicavam uma população de 104 mil pessoas. Isto significaria que Santo Antônio já tem uma população igual àquela que tinha antes do desmembramento de Águas Lindas em 1996. Ainda de acordo com a prefeitura, esta população se divide em $85 \%$ na área urbana e $15 \%$ na sua área rural.

\section{A metodologia adotada pelo IBRAD}

Para melhor compreensão das análises propostas nesse documento e das conclusões por elas geradas, é importante entender como se deu o processo de capacitação em planejamento do desenvolvimento sustentável adotado pelo IBRAD e, mais ainda as implicações das características dos assentamentos humanos recentes sobre este processo.

A discussão da metodologia de capacitação adotada pelo IBRAD nos remete à definição das linhas gerais do processo de capacitação definidas de forma conjunta com os demais parceiros do consórcio e, com base nessa compreensão, discutir os ajustes e adaptações propostas pelo IBRAD e suas finalidades.

A primeira definição metodológica foi a distinção entre a carga de capacitação para o Fórum e para a Equipe Local (ELO), dada a característica de instância deliberativa do primeiro e de agente executivo da segunda. A metodologia achou pertinente que se enfatizasse o processo de “capacitação para a participação" para o Fórum e de capacitação operacional para os membros da ELO.

Uma segunda definição adotada, principalmente, em função das distâncias que separavam as localidades em que cada instituição iria atuar, foi a de trabalhar com momentos que alternavam trabalho de capacitação presencial e intervalos monitorados.

Nos momentos de capacitação presencial, a equipe da instituição capacitadora estaria nas localidades, reunida com o Fórum e/ou com a ELO, desenvolvendo os temas e conteúdos previstos. Basicamente, seriam três momentos de capacitação presencial, com os seguintes objetivos:

- Primeiro momento: apresentação do programa, definição de seus objetivos, discussão do conceito de desenvolvimento local integrado e 
sustentável; organização do Fórum e da ELO, definição dos seus papéis, organização dos trabalhos e da agenda; definição da visão de futuro da localidade; e realização do diagnóstico participativo.

- Segundo momento: validação do diagnóstico participativo; discussão sobre as alternativas para solução dos problemas e dificuldades identificados para o aproveitamento das potencialidades locais; e definição de projetos que iriam compor o PDLIS.

- Terceiro momento: validação dos projetos selecionados; estruturação do PDLIS; definição de prioridades e elaboração da agenda local; discussão sobre o papel da agenda e do pacto; e delegação das atribuições do Fórum e da ELO no que se refere à gestão da implementação do PDLIS.

Entre os primeiro/segundo e segundo/terceiro momentos, as ELO estariam trabalhando naquilo que se convencionou chamar: intervalo monitorado, com uma duração que deveria variar entre 10 e 15 dias.

No primeiro intervalo, a expectativa era de que os membros da equipe estivessem trabalhando no levantamento dos dados e informações que estivessem faltando para complementar o diagnóstico participativo, enquanto que, no segundo momento, eles estariam trabalhando no detalhamento dos projetos e ações que haviam sido propostos pelo Fórum.

Ao final desse processo, a expectativa era a de permitir que todos os membros dos fóruns tivessem sido expostos aos conteúdos previstos no programa e que a ELO, em especial, tivesse aplicado, na prática, alguns desses conceitos, especialmente aqueles relativos à construção do diagnóstico e à identificação de possibilidades de solução.

A proposta era a de que todos tivessem passado por um processo de capacitação política em termos da importância da organização e da participação da sociedade civil organizada na superação dos seus problemas e no desenvolvimento de suas potencialidades.

Entretanto, ao se iniciar o processo de capacitação, foram adotadas algumas medidas específicas que também precisam ser consideradas.

Uma primeira, e muito significativa, que valeu para todas as 13 localidades em que o Instituto iria atuar, foi a de não tentar caracterizar o trabalho como sendo um curso. Isso porque não cabia igualar o processo de capacitação a um curso regular. Na verdade, o que se pretendia era transformar o processo de capacitação em um esforço de construção coletiva onde o papel da instituição capacitadora era o de assessorar o Fórum e a ELO nas suas iniciativas.

No caso do processo de capacitação nas localidades do DF e de Goiás, o IBRAD procurou experimentar um processo ainda mais democrático na construção desse processo de capacitação, flexibilizando a própria agenda de trabalho dos capacitadores. Na perspectiva do IBRAD, a lógica por trás dessa decisão era a de que, uma vez que os Fóruns e as 
ELO tivessem maior liberdade para definir datas e cargas horárias dos trabalhos, seria mais fácil uma participação mais ampla das lideranças e, principalmente, uma maior freqüência dessas pessoas aos momentos presenciais de capacitação.

Assim, se por um lado, as características e especificidades dos assentamentos humanos recentes, nos quais o IBRAD atuou, produziram impactos sobre o trabalho que vinha sendo realizado, também as decisões metodológicas tomadas quanto ao processo de capacitação tiveram suas repercussões nas conclusões que aqui serão formuladas. Entretanto, acreditamos que essas não possam ser supervalorizadas. Recorrendo a Franco (1999), observa-se que:

“Conquanto a capacitação das populações para a gestão local do processo de desenvolvimento constitua um ingrediente necessário no cardápio de elementos caracterizadores do DLIS, o centro do processo de promoção do DLIS não pode ser a metodologia que produz um plano como desejo organizado de futuro de uma coletividade, nem a pedagogia que consiga envolver os atores populares na consecução das tarefas de planejamento participativo. A sociedade não se transformará por força da implementação de um bom processo educativo, que transforme os excluídos de pacientes em agentes da construção do seu futuro, embora isso seja bom. As metodologias são ferramentas, as pedagogias são instrumentos (e tudo isso é necessário) mas não vão salvar o mundo.”

Ainda como preconiza esse mesmo autor, o centro do processo de promoção do DLIS deve ser a política, o que nos traz de volta à discussão sobre as características das localidades analisadas e de como se dá o processo de gestação das políticas (policies) e, tão relevante, como se faz política (politics) nessas localidades.

Porém, como um dos referenciais que será utilizado como indicador para a discussão da participação das lideranças comunitárias no PCA está a freqüência que essas lideranças tiveram nas reuniões dos FDL. A metodologia adotada pelo IBRAD também gerou impactos negativos sobre esse indicador. E tais impactos precisam ser expurgados para ter uma boa avaliação dos efeitos das características dos assentamentos humanos recentes sobre a questão da participação.

\section{A sensação de pertencimento}

O processo de rápido crescimento populacional que caracteriza todas as sete localidades consideradas como assentamentos humanos recentes, somado a outras características decorrentes do perfil sócio-cultural dessas 
populações, levou à conformação de uma série de peculiaridades desses agrupamentos urbanos que, de forma bastante clara, influenciou o desenvolvimento do trabalho de indução do desenvolvimento sustentável no nível local.

A primeira dessas características está relacionada ao que denominamos a sensação de pertencer ao local. $O$ trabalho desenvolvido junto aos FDL deixou bastante evidente a falta de uma relação de pertencimento entre a maioria das pessoas que habitam os locais e o próprio local.

Essa falta de uma sensação de pertencer ao local pôde ser observada com maior clareza nos municípios do estado de Goiás. Nos diagnósticos participativos, era comum que os participantes identificassem como causa importante do atraso no desenvolvimento local coisas como:

- vergonha de se declarar morador do município - segundo os participantes, muitos dos moradores daquelas localidades se declaram moradores de Brasília ${ }^{14}$;

- a falta de compromisso com o desenvolvimento do local, inclusive optando por ter sua vida social fora do município; e

- a sensação de que a estada naquele município é algo transitório e passageiro.

Esses fenômenos podem ser justificados pela própria falta de tempo para que se construísse uma cultura própria do local. Ao levarmos em conta que as pessoas que estão naquelas comunidades vieram dos mais distantes lugares do país, buscando Brasília, e que, por opção ou falta de alternativa, estão assentadas naquelas localidades, é perfeitamente compreensível esse sentimento. Daí, um primeiro desafio a enfrentar nas ações nessas localidades: a inexistência de uma comunidade, como afirma Demo (1988):

"Tomando como referência a comunidade, pode-se afirmar que a condição básica para um grupo social sentir-se comunidade é possuir lastro cultural próprio que o identifique. Esse lastro cultural próprio cristaliza a história da comunidade, os valores e símbolos cultivados, os modos de ser e de fazer, bem como os modos de produzir. Por mais pobre que seja, não há comunidade que não tenha traços característicos produzidos na criatividade histórica e gerados no contexto de suas potencialidades concretas. Caso contrário, sequer seria comunidade" (op.cit.).

E a falta de uma comunidade tem implicações diretas na participação e no processo político ou na participação enquanto processo político. Recorrendo ao mesmo autor, temos que "componente essencial do sentimento de comunidade, do sentir-se membro de um determinado grupo, de participar em um projeto concreto de vida", o que leva à afirmação de 
que a "cultura comunitária é parteira da participação". Nisso ele concorda com Pizzorno (1975) que afirma:

"la participación política es expressión de pertenencia a un cierto grupo social: cuanto más segura es la pertenencia, tanto mayor será la participación política."

Ora, considerando-se que a participação é condição básica para a implementação de um processo de desenvolvimento sustentável, superar essa restrição é um dos desafios que as instituições que se envolvem nesse tipo de iniciativa precisam enfrentar. Reproduzindo o que Demo já afirmava em 1988:

"Dificulta extremamente a participação, o fato de que muitas comunidades já são quase apenas conglomerados humanos, tangidos pela repressão da pobreza sócio-econômica e política. Processos migratórios compulsivos, por exemplo, destroem raízes, sem as substituírem."

\section{Líderes recentes e representatividade}

Uma das mais significativas particularidades dos assentamentos humanos recentes, naquilo que interessa ao desenvolvimento sustentável na perspectiva aqui proposta, é o processo de formação de suas lideranças e a capacidade, dessas lideranças, de representarem as suas comunidades, e destas de se sentirem representadas.

Inicialmente, devemos destacar que por liderança não necessariamente deve-se compreender cabos eleitorais, embora nos assentamentos humanos recentes, seja bem mais difícil distinguir lideranças comunitárias de representantes de políticos eleitos nas demais localidades.

Uma liderança é qualquer pessoa capaz de representar os interesses de determinado grupo ou segmento da sociedade e, mais importante, de este grupo reconhecê-la como seu representante. Além desse tipo de liderança, em comunidades menores, existe um outro tipo de líder que é aquele que, embora não seja uma liderança representativa, atua como formador de opinião junto aos membros da comunidade, afetando seu posicionamento político ${ }^{15}$.

Em geral, em assentamentos humanos recentes o que encontramos são lideranças também recentes, ou ainda, lideranças em processo de formação. Na maioria dos casos, aquelas pessoas que se apresentam como líderes da comunidade são indivíduos que ainda estão desenvolvendo as primeiras iniciativas no que se refere à organização da comunidade e ao seu reconhecimento enquanto líder. Isso, quando não aparecem pseudolíderes e líderes de si mesmo. 
Como consequiência desse perfil de lideranças, no processo de organização dos FDL, a participação dessas pessoas na realização do diagnóstico participativo e nas demais etapas do processo de planejamento é fortemente marcada por uma preocupação em se afirmar como líderes locais, gerando um ingrediente adicional na mediação dos interesses do Fórum, que é a ocupação dos espaços políticos.

Nas localidades onde as lideranças já estão consolidadas, as diferenças e as disputas políticas também ocorrem, é óbvio. Mas, diferentemente do observado nos assentamentos humanos recentes, há uma maior constância e regularidade na disputa política. Os grupos estão melhor organizados, e seu posicionamento na arena política, inclusive no que se trata à capacidade de se articular com os outros grupos, está mais claramente definido.

Essa diferença entre lideranças em formação nos assentamentos humanos recentes e lideranças comunitárias tradicionais, pode ser explicada como fruto da própria falta de experiência (dos líderes e dos liderados) em participação política. Como afirma Pizzorno (1975), a participação política de um indivíduo é maior quanto mais alta for a sua posição sociall ${ }^{16}$.

Por sua vez, a posição social pode ser obtida de diversas maneiras, entre as quais, pode ser destacado o tempo de residência em certa localidade. Ou seja, em localidades recentes ainda não houve tempo suficiente para que o tempo de residência e outros aspectos relevantes pudessem gerar lideranças políticas reconhecidas.

Empiricamente falando, um indicador que serve para demonstrar o pequeno grau de influência das lideranças é no nível de presença das comunidades no evento de lançamento do PCA nos diversos municípios. Como previsto na metodologia, cabia à Instituição Capacitadora realizar um evento de lançamento do programa em cada município, com ampla participação da comunidade.

Contando com o apoio das interlocuções estaduais, das prefeituras municipais e das administrações regionais, os parceiros no programa contatavam as mais variadas lideranças locais e solicitavam que elas arregimentassem seus liderados, para que o lançamento do programa pudesse ser realizado com o maior número possível de pessoas (o mínimo recomendado pelo programa era de 50 pessoas).

Ao analisarmos a participação no evento de lançamento do programa nas oito localidades estudadas, veremos que, apesar das reuniões de mobilização de lideranças realizadas para preparar o evento ${ }^{17}$, apenas Padre Bernardo e Planaltina de Goiás tiveram uma participação mais representativa. Porém, se analisarmos esses números em relação à população de cada localidade, veremos que, à exceção de Padre Bernardo, a capacidade dos líderes de atraírem seus liderados para o programa foi, no mínimo, discreta. 


\begin{tabular}{l|c|r|c}
\hline Local & Participantes & População $^{18}$ & Part. Relativa $^{19}$ \\
\hline Águas Lindas/GO & 65 & 130.000 & 0,50 \\
\hline Brazlândia/DF & 67 & 62.000 & 1,08 \\
\hline Novo Gama/GO & 70 & 71.000 & 0,99 \\
\hline Padre Bernardo/GO & 170 & 17.000 & 10,00 \\
\hline Paranoá/DF & 50 & 60.000 & 0,83 \\
\hline Planaltina/GO & 130 & 58.500 & 2,22 \\
\hline Riacho Fundo/DF & 48 & 38.000 & 1,26 \\
\hline $\begin{array}{l}\text { Santo Antônio do } \\
\text { Descoberto/GO }\end{array}$ & 70 & 67.000 & 1,04 \\
\hline
\end{tabular}

Esse problema da representatividade das lideranças dos assentamentos humanos recentes também se reflete na participação políticopartidária e eleitoral. Um rápido levantamento pode demonstrar que há uma aparente relação entre o tempo de existência de uma determinada localidade; o ritmo de seu crescimento, ou melhor, seu pico de crescimento populacional; e a participação eleitoral relativa. O quadro a seguir demonstra a situação dos cinco municípios do estado de Goiás em estudo ${ }^{20}$ :

\begin{tabular}{l|c|l|c|c|c}
\hline Município & Emancipação $^{(\mathrm{a})}$ & $\begin{array}{l}\text { Pico de } \\
\text { Crescimento }\end{array}$ & População & Eleitorado $^{(\mathrm{c})}$ & \% $^{(\mathrm{d})}$ \\
\hline Águas Lindas & 1995 & Após 1995 & 130.000 & 19.794 & 15,2 \\
\hline Novo Gama & 1995 & $1990 / 1995$ & 71.000 & 35.285 & 49,7 \\
\hline Padre Bernardo & 1964 & $1970 / 1980$ & 17.000 & 12.163 & 71,5 \\
\hline Planaltina & $1891^{21}$ & $1980 / 1990$ & 58.500 & 43.182 & 73,8 \\
\hline Sto. Antônio & 1982 & $1990 / 1995$ & 67.000 & 34.288 & 51,2 \\
\hline
\end{tabular}

a) ano em que o município foi emancipado; b) período em que o município apresentou o mais acentuado crescimento populacional; c) número de eleitores cadastrados no município segundo o TRE/GO; e d) participação relativa, eleitorado/população.

Além de ser grande a diferença dos valores relativos encontrados, esses números tornam-se mais claros quando comparados, por exemplo, com a média do estado de Goiás, que tem $63,2 \%$ de sua população cadastrada como eleitores, indicando, mais uma vez, a influência do tempo sobre a participação política e a sensação de pertencer a uma determinada localidade.

Embora seja indiscutível que outras variáveis concorrem para o número de eleitores cadastrados em um determinado município, os números apresentados evidenciam uma certa correlação entre tempo de pertencimento e participação político-eleitoral, gerando uma série de desdobramentos sobre a qualidade dos processos políticos participativos estimulados. 
O caso de Águas Lindas é, certamente, paradigmático. Possuindo apenas $15 \%$ de sua população como eleitores, quais devem ser os perigos de distorção da representatividade política? Indo mais adiante, até que ponto representantes eleitos com a participação de menos de um quinto da população representam de fato o interesse do conjunto dos 130.000 moradores? E esses moradores se sentem representados? Esse é talvez o maior dilema da questão da participação nos assentamentos humanos recentes.

\section{O urbano x o rural}

Uma outra característica, freqüentemente, observada nos trabalhos desenvolvidos nesses assentamentos humanos recentes, foi um elevado grau de hostilidade entre o urbano e o rural, especialmente, se comparado com o dos municípios do Mato Grosso do Sul.

Embora sem dispor de um volume de informações suficiente para explicar essa relação de conflito, o que nos parece bastante evidente é que, nessas localidades, o desenvolvimento da área urbana não é conseqüência do desenvolvimento do município, baseando-se no desenvolvimento das potencialidades econômicas da área rura ${ }^{2}$. Na realidade, $\mathrm{o}$ crescimento da área urbana desses municípios deu-se às custas de uma ocupação pouco racional e descontrolada das áreas rurais. Como ressalta Dos Anjos (1998):

"é relevante observar o espaço do cerrado que está sendo desfigurado por loteamentos (16.533 hectares). O conflito dos espaços urbano/rural está bem caracterizado nos dados aproximados de perda de 5.400 hectares (área agrícola) e de 1.503 hectares (reflorestamento) para a implementação de parcelamentos."

No trabalho desenvolvido pelo IBRAD junto às comunidades do entorno e do DF, esse conflito se manifestava nas freqüentes discussões e exigências quanto ao controle do processo de ocupação das áreas (da parte dos produtores rurais) e quanto à necessidade de se regularizar os lotes e terrenos (da parte dos moradores e dos comerciantes da área urbana).

Uma situação que pode exemplificar esse situação de "conflito de interesses" ocorreu na localidade de Paranoá/DF. Nessa localidade, quando se iniciou o processo de capacitação, a EMATER/DF tinha acabado de realizar um trabalho de organização das comunidades rurais para estruturação do Conselho Regional de Desenvolvimento Rural (CRDR) e para a elaboração do Plano Regional de Desenvolvimento Rural $(\mathrm{PRDR})^{23}$.

Em função dessa organização, os representantes das comunidades rurais impuseram, quando da montagem do FDL, que este fosse limitado 
a 24 participantes e, principalmente, que fossem 12 representantes indicados pelas lideranças da área urbana e 12 representando as comunidades rurais organizadas da RA.

\section{Participação, vetor de desenvolvimento e DLIS}

O primeiro desafio proposto nessa discussão é o que tenta correlacionar as características percebidas nas localidades identificadas como assentamentos humanos recentes, que conformaram-se nos tópicos anteriormente relacionados, e seus impactos sobre o processo de promoção de iniciativas de DLIS, ou sobre quaisquer outras empreitadas com essas características.

Basicamente, nosso argumento assenta-se sobre duas variáveis básicas para essa discussão: a primeira se relaciona com os impactos dessas características sobre a participação da comunidade no processo de condução e discussão das estratégias de desenvolvimento sustentável; já a segunda se orienta para a própria discussão do desenvolvimento, ou melhor, do vetor de desenvolvimento que poderá orientá-lo e contribuir para a sua sustentabilidade.

Antes de dedicar maior atenção para esses dois aspectos, parece pertinente iniciar essa discussão pelo próprio conceito de desenvolvimento local e suas variantes, para que se possa avançar na análise de como essas duas variáveis se relacionam com o processo que se pretendia introduzir com o trabalho das Instituições Capacitadoras e demais parceiros.

Partindo da premissa de que há relativo consenso entre as diversas correntes sobre desenvolvimento sustentável, este pode ser conceituado como o "processo de mudança social e elevação das oportunidades da sociedade, compatibilizando, no tempo e no espaço, o crescimento e a eficiência econômicos, a conservação ambiental, a qualidade de vida e a eqüidade social, partindo de um claro compromisso com o futuro e da solidariedade entre gerações"(Buarque, 1994) ${ }^{24}$.

Entretanto, cabe especificar o conceito de desenvolvimento local, integrado e sustentável que foi proposto para referenciar as iniciativas de promoção do desenvolvimento preconizadas pelo PCA, uma vez que foi essa abordagem que orientou o trabalho desenvolvido pelo IBRAD nas diversas comunidades de Goiás, Mato Grosso do Sul e do Distrito Federal. Como observa Franco (1999):

"o que hoje se chama de DLIS (Desenvolvimento Local Integrado e Sustentável) é uma denominação ampla para vários tipos de processos de desenvolvimento local. Lançada institucionalmente em 
1997, pelo Conselho da Comunidade Solidária, a expressão foi adotada pela maioria dos atores que se dedicam ao desenvolvimento local no Brasil. Utilizam-na hoje tanto aqueles que continuam enfatizando o papel determinante exclusivo do fator econômico quanto aqueles que têm uma visão mais sistêmica do processo de desenvolvimento, como, por exemplo, os que trabalham com a chamada Agenda 21 Local.”

Mais que isto, na perspectiva da proposta de trabalho do Comunidade Solidária, o que "chamamos de DLIS nada mais é do que uma metodologia, lato sensu, para desencadear"(op.cit.) o processo de promoção do desenvolvimento. Neste sentido, e mais uma vez recorrendo ao mesmo autor, a metodologia preconizada deve contemplar:

- a capacitação para a gestão local;

- a criação de uma nova institucionalidade participativa (conselho, fórum, agência ou órgão similar, de caráter multissetorial, plural e democrático, encarregado de coordenar o processo de desenvolvimento na localidade);

- diagnóstico e planejamento participativos; a construção negociada de uma demanda pública da localidade (em geral, materializada na forma de um plano de desenvolvimento ou de uma agenda local de prioridades de desenvolvimento);

- a articulação da oferta estatal e não-estatal de programas e ações com a demanda pública da localidade; a celebração de um pacto de desenvolvimento na localidade (ou similar, tendo por base a agenda local pactuada);

- fortalecimento da sociedade civil (por meio do estímulo à ação cidadã, do apoio à construção de organizações sem fins lucrativos, sobretudo de caráter público, da celebração de parcerias entre os poderes constituídos e tais organizações e da promoção do voluntariado);

- fomento ao empreendedorismo (por meio da capacitação, do crédito e do aval para impulsionar e apoiar a criação e o desenvolvimento de novos negócios sustentáveis, com fins lucrativos mesmo); e

- a instalação de sistemas de monitoramento e avaliação.

\section{A participação}

Como se observa da metodologia descrita por Franco, a participação da comunidade, seja na organização e operação da nova institucionalidade participativa, ou na elaboração dos diagnósticos e planos participativos, é condição fundamental para a qualidade do movimento que se pretende instalar. Neste sentido, cabe verificar que as características identificadas como típicas dos assentamentos humanos recentes afetam à qualidade do processo participativo. 
Tentando restringir o objeto dessa discussão sobre características dos assentamentos, a participação política e a promoção de ações voltadas para o desenvolvimento sustentável, precisamos relacionar os impactos dessas características sobre uma determinada espécie de participação, a participação civil, como definida por Pizzorno (1975), que indica:

"La participación civil ${ }^{25}$ en la política es la que fue analizada más extensamente en el presente trabajo. También ella está integrada al sistema de relaciones que vinculan la sociedad civil con el Estado, pero es expresión de la demanda y de las imposiciones que aquélla dirige a éste." “Además, por las razones analizadas hasta aquí, la intensidad de este tipo de participación es función de la posición social, o sea que es mayor cuanto más elevada es la posicion social."

Especificamente, a adoção desta tipificação de participação e a seleção de um tipo para caracterizar o objeto primordial dessa análise importa o reconhecimento de uma forma específica de relação Estado/ sociedade que é mais relevante para a forma de intervenção proposta pelo PCA. Mais importante ainda, como reconhece Pizzorno (1975):

"Una amplia difusión de este tipo de participación indica un alto grado de integración entre sociedad civil y Estado; ausencia de polarización social de la política (las divisiones entre las partes políticas no corresponden a las divisiones de clase, o a otras divisiones radicales - por ejemplo, religiosas o étnicas - presentes en la sociedad; una débil incidencia de los partidos de masa."

Neste sentido, o que se observa nos assentamentos humanos recentes ora analisados - e possivelmente em outras situações que se aproximem deste modelo - é que não existe, de princípio, uma cultura de participação civil consolidada e arraigada. Pelo contrário, é muito mais frequiente encontrar modelos clientelistas a mediar as relações entre Estado e sociedade, modelos que se reproduzem a partir da própria conjuntura política que eles contribuem para conformar.

Adicione-se a esta falta de cultura para a participação a já mencionada falta de sensação de pertencimento e, por consequiência, a própria falta de um sentimento de comunidade, dificultando as ações propostas no programa ou qualquer outra iniciativa assemelhada, recorrendo a Jara (1999):

"No mundo local, onde a comunidade ainda é comunidade, ainda existem realidades sociais, historicamente determinadas, caraterizadas pela ação conjunta, redes de sociabilidade afirmadas 
na reciprocidade e cooperação, esperança no outro, homogeneização de interesses em torno de reivindicações e demandas coletivas, emocionais coletivos solidários, identidades, relacionamentos não-competitivos, sujeitos históricos que revelam sentimentos nãoindividualistas como proteção, lealdade, dignidade e honestidade."

A falta de todos esses ingredientes facilita a construção de modelos de relação de dependência entre os membros da localidade. Ou, como descreve Putnam (1995), tais localidades ao não encontrarem na sua história evidências e experiências que indiquem as soluções horizontais (solidariedade, confiança recíproca) como alternativa para a superação dos seus problemas, tendem a recorrer a relacionamentos verticais e dependentes, especialmente as relações de clientela.

Isso, segundo o autor, caracterizaria uma evidência de baixo capital social. Capital este que é fundamental para a construção de uma sociedade, politicamente estável e saudável. Esse capital é, assim como o capital econômico e o capital humano, ferramenta indispensável para a promoção do desenvolvimento sustentável e, nos assentamentos humanos recentes, ele é insumo raro. Como propõe Jara (1999):

"O que é percebido como capital social depende, por conseguinte, da cultura, das tradições e da estrutura que se observa. Das bases éticas e morais compartilhadas entre as pessoas e atores sociais. Ethos, ética em grego, diz respeito à morada humana, tudo aquilo que ajuda à construção de um ambiente saudável: "materialmente sustentável, psicologicamente integrada e espiritualmente fecunda". A moral, do latim mos, mores, diz respeito aos costumes e as tradições. Quando um comportamento ou relacionamento é considerado bom e vira referência coletiva, surge uma tradição. A moral está vinculada a um sistema de valores, próprio de cada cultura e caminho espiritual (Leonardo Boff, 1997). Numa sociedade heterogênea, diferenciada, dividida em classes e atores sociais, temos que perguntar. O capital social de quem? Os valores e prioridades de quem? Como construir capital social para o desenvolvimento local sustentável?"

Ora, se em uma sociedade heterogênea e dividida em classes sociais devemos estar atentos a quem está enunciando valores e prioridades e com o capital social de quem se está trabalhando. Em uma sociedade fragmentada (política, cultural e economicamente como as encontradas nos assentamentos humanos recentes) não só essas questões calam mais fundo, como tornam ainda mais desafiante a tarefa de se construir um projeto coletivo de promoção do desenvolvimento local, em bases integradas e sustentáveis. 
Essas dificuldades podem ser materializadas, ainda para fins da discussão sobre os efeitos delas sobre a proposta do PCA, em indicadores da participação das lideranças no processo de capacitação proposto pelo instituto.

Embora seja difícil avaliar a participação ou a qualidade da participação das lideranças locais no PCA, e sem querer reduzir participação à presença, a frequiência é condição necessária, embora não suficiente, para participar, e o único indicador confiável que o IBRAD dispunha para avaliar esse quesito.

O quadro a seguir apresenta, para cada município onde o IBRAD desenvolveu o trabalho, o número de pessoas que foram indicadas para participar dos Fóruns e aquelas que, ao final de três meses de trabalho, receberam o certificado de participação $0^{26}$ :

\section{Distrito Federal}

\begin{tabular}{l|c|c|c}
\hline Localidade & Indicados & Certificados emitidos & \% \\
\hline Brazlândia & 35 & 14 & 40 \\
\hline Paranoá & 24 & 07 & 29 \\
\hline Riacho Fundo & 23 & 12 & 52 \\
\hline Total & 82 & 33 & 40 \\
\hline
\end{tabular}

Goiás

\begin{tabular}{l|c|c|c}
\hline Localidade & Indicados & Certificados emitidos & \% \\
\hline Águas Lindas & 29 & 10 & 34 \\
\hline Novo Gama & 25 & 10 & 40 \\
\hline Padre Bernardo & 33 & 26 & 79 \\
\hline Planaltina de Goiás & 20 & 13 & 65 \\
\hline Santo Antônio do & 26 & 14 & 54 \\
Descoberto & 133 & 73 & 54 \\
\hline Total & & & \\
\hline
\end{tabular}

Mato Grosso do Sul

\begin{tabular}{l|c|c|c}
\hline Localidade & Indicados & Certificados emitidos & \% \\
\hline Angélica & 26 & 23 & 88 \\
\hline Bataguassu & 25 & 25 & 100 \\
\hline Nioaque & 28 & 27 & 96 \\
\hline Porto Murtinho & 24 & 24 & 100 \\
\hline Sete Quedas & 24 & 21 & 88 \\
\hline Total & 127 & 120 & 94 \\
\hline
\end{tabular}

Os dados acima demonstram que a participação das lideranças em Goiás e Distrito Federal, ou seja, nos assentamentos humanos recentes, 
ficou bem abaixo dos resultados encontrados em Mato Grosso do Sul, onde as características dos municípios são bem diferentes do quadro analisado. Entretanto, não se pode reputar exclusivamente à realidade local os resultados obtidos. Outras variáveis tiveram importância nesse processo, em especial a metodologia adotada pelo IBRAD, como anteriormente mencionado, o que justifica acrescer os números encontrados no Mato Grosso do Sul.

Tentando dimensionar o impacto das mudanças implementadas pelo IBRAD na metodologia prevista, optou-se por adotar como parâmetro de referência a média de certificação do estado do Mato Grosso do Sul, que ficou com 94\%, e compará-la com o resultado encontrado na única localidade, das oito analisadas, que não poderia ser enquadrada como assentamento humano recente, isto é, Padre Bernardo (79\%).

Considerando válido esse raciocínio, pode-se estimar que a metodologia adotada pelo IBRAD foi responsável por um incremento de 15 pontos percentuais na taxa de evasão dos participantes do processo de capacitação. Somando-se aos seis pontos percentuais que podem ser reputados a causas variadas, o restante poderia ser associado às dificuldades de se estimular a participação em localidades com o perfil descrito para os assentamentos humanos recentes ${ }^{27}$.

Ou seja, os aspectos que caracterizam uma localidade como as que estão sendo analisadas, em especial a baixa acumulação de capital social, gera efeitos significativos sobre a participação da comunidade e de suas lideranças. Reconhecer tais restrições implica a necessidade de se construir intervenções mais adequadas.

Por fim, cabe lembrar que a participação das lideranças e da própria população local no processo de construção do DLIS, ativo mais representativo do capital social destas localidades, é um recurso que precisa ser identificado, lapidado e/ou construído, como alternativa para alavancar seu desenvolvimento. Já o PCA precisa dispor de meios para alcançar esse desiderato.

\section{O vetor econômico do desenvolvimento}

Por trás da lógica da promoção do desenvolvimento sustentável, mormente naquilo que ser refere aos aspectos econômicos (crescimento e eficiência) do desenvolvimento, reside a necessidade de se identificar vantagens comparativas que o local apresenta com relação às demais localidades.

Em outros termos, embora não deva existir qualquer relação de subordinação entre as vertentes do desenvolvimento (econômico, social e ambiental), a sustentabilidade depende da identificação de potencialidades 
ou diferenciais competitivos que dêem o suporte econômico à dinâmica que se pretende induzir, e que aqui chamaremos de vetor econômico do desenvolvimento. Isto porque:

"O desenvolvimento local é um modo de promover o desenvolvimento que leva em conta o papel de todos esses fatores para tornar dinâmicas potencialidades que podem ser identificadas quando olhamos para uma unidade sócio-territorial delimitada." (Franco, 1999)

Assim, era tarefa do $\mathrm{PCA}^{28}$ realizar estudos sobre as potencialidades econômicas e as vantagens comparativas dos municípios e RA nas quais o IBRAD trabalharia, com a finalidade de subsidiar o processo de planejamento participativo e a elaboração dos PDLIS.

Porém, nos assentamentos humanos recentes analisados nesse estudo, essa tarefa mostrou-se bem mais complexa que o esperado, segundo relato dos próprios consultores do SEBRAE que participaram dessa fase do trabalho. Na maioria dos municípios, era difícil identificar potencialidades econômicas que fossem além da exploração do mercado existente no nível local, cuja demanda estava fortemente influenciada pelo desempenho econômico dos pólos dinamizadores do desenvolvimento, no caso, Brasília e o complexo Taguatinga/Ceilândia/Samambaia.

Ou seja, nos assentamentos humanos recentes ${ }^{29}$, o vetor econômico do desenvolvimento local é variável, fortemente dependente da dinâmica de desenvolvimento dos pólos econômicos a que eles são lindeiros. Daí a dificuldade encontrada para se estabelecer rumos para o crescimento econômico, uma vez que era baixa a capacidade de influenciar, apenas com os recursos locais, toda a dinâmica econômica do DF e entorno.

Isso não implica a impossibilidade de se estimular o desenvolvimento sustentável das localidades estudadas. Pelo contrário, apenas torna mais complexa a definição de estratégias e propostas de alavancagem desse desenvolvimento, uma vez que variáveis extremamente relevantes para o sucesso na empreitada estão, em maior ou menor escala, fora da governabilidade $^{30}$ dos atores que estão envolvidos na discussão.

$\mathrm{Na}$ verdade, do ponto de vista prático, o que se faz necessário é o desenvolvimento de metodologias e procedimentos que dêem conta dessas características, tão própria dos assentamentos humanos recentes.

\section{Desafios a enfrentar}

Mais do que tentar pintar um quadro cinzento da realidade encontrada nos municípios goianos do entorno do DF e das RA onde o IBRAD atuou, o objetivo desse documento é dar um depoimento da situação encontrada nessas localidades e discutir o PCA à luz deste quadro. 
Se, como propõe Franco (1999), "implantar o DLIS é desinstalar um velho conjunto de práticas, substituindo-as por outras práticas — mais democráticas, mais cidadãs e mais sustentáveis", a missão das instituições capacitadoras e demais atores que participam do PCA deve ir além da mera construção de um plano de desenvolvimento com metodologias que permitam a participação da comunidade local.

Há que se dar a devida atenção à tarefa de desinstalar o modelo velho e o forte viés político e cultural que está a ele associado. Na verdade, é fundamental discutir métodos, ferramentas e práticas que sejam efetivamente transformadoras e promotoras do desenvolvimento sustentável. Como reconhece o próprio Augusto de Franco (1999):

"esta tarefa não se pode efetivar sem política. É o óbvio e deveria ser reconhecido como tal: o processo de Desenvolvimento Local Integrado e Sustentável — embora se constitua como metodologia, lato sensu, para promover o desenvolvimento sustentável por meio da participação multisetorial de diversos agentes, governamentais, sociais e empresariais, no planejamento, na execução, no monitoramento e na avaliação de ações integradas e convergentes em localidades determinadas - deve ter como centro a política e não as metodologias, stricto sensu, voltadas para motivar e qualificar a participação dos atores locais nessas ações. Estas metodologias de capacitação, necessárias sem sombra de dúvida, devem ser instrumentos da estratégia política e não o inverso."

Em outras palavras, é necessário reforçar os instrumentos de formação política dessas comunidades ou, mais especificamente, é fundamental investir na formação e desenvolvimento do capital social e do capital humano dessas localidades. Como alerta Jara (1999):

"O processo de desenvolvimento não é exclusivamente objetivo. A transição para uma sociedade sustentável será um processo possível quando sejam valorizados certos elementos estratégicos invisíveis, como o capital humano e o capital social, a participação social e o empoderamento das pessoas e organizações. Quando, sem receio, seja possível introduzir nas considerações do desenvolvimento valores, tais como a confiança, compaixão, solidariedade, amor e beleza, todos eles invisíveis e não-racionais.

As soluções para superação da pobreza, rural e urbana, estão na organização da sociedade, na construção de novas condições institucionais baseadas na cooperação, visando acumular capital social, um sistema de valores comuns fundamentados em princípios compartilhados de confiança. Esses recursos invisíveis que cimentam o tecido social, possibilitando a transição para um novo padrão de 
desenvolvimento sustentável, nutrem-se da real democracia que se fundamenta na vontade do povo. Daí a importância de expandir a cidadania, de empoderar aos cidadãos, alimentando a horizontalidade dos contatos, das trocas, os relacionamentos de reciprocidade, maior capacidade da sociedade civil para controlar situações vulneráveis e orientar o rumo dos processos de desenvolvimento. Eis a importância de construir capital social."

Se isso é verdade para as comunidades em geral, no caso específico dos assentamentos humanos recentes, esta tarefa é ainda mais desafiadora. Reveste-se de importância o processo de mobilização e organização da sociedade. Também, em função da própria situação de handicap, parece necessário mais tempo para cimentar esses laços sociais, para se trabalhar no apoio à formação de lideranças e de processos políticos efetivamente participativos e democráticos. Há que se investir nesta formação de capital social pois, como afirma Putnam (1995):

"Tal como sucede com o capital convencional, os que dispõem de capital social tendem a acumular mais. Uma vez tendo criado suas primeiras instituições de pequeno porte, um grupo de indivíduos pode utilizar o capital social, assim gerado, para solucionar problemas de maior monta através de mecanismos institucionais mais complexos."

É importante então estimular a construção, nessas localidades, de tais primeiras instituições sociais. E, talvez não seja mais recomendado começar pela criação de um Fórum de desenvolvimento municipal, uma vez que nesses municípios incidem algumas variáveis que tendem a comprometer a efetividade dessa nova instituição, em especial as seguintes:

a) o tamanho dos municípios, pois, em geral, são municípios com bem mais de 50 mil habitantes ${ }^{31}$ o que dificulta, com o pouco tempo que se dispõe para a estruturação do fórum, conseguir arrebanhar um grupo de pessoas que conforme uma representação bem fidedigna daquela localidade;

b) os diversos locais em um só local. No caso dos assentamentos humanos recentes, como o processo de ocupação dos espaços, em regra, se deu de forma desordenada, o que se observa é uma variedade de locais, com dinâmicas próprias e independentes. Assim, quando do processo de diagnóstico participativo e de planejamento ou se opta por desconhecer as espeficidades, elaborando uma proposta bem genérica, ou acaba por se elaborar vários planos distintos dentro de um mesmo documento; e

c) o desconhecimento que as lideranças costumam apresentar sobre a realidade e as dificuldades enfrentadas em outras localidades do mesmo 
município, o que dificulta uma melhor negociação de prioridades entre os participantes do Fórum de Desenvolvimento.

Por outro lado, não se pode perder de vista a enorme dependência econômica que essas localidades possuem com relação aos centros aos quais elas se vinculam. Essa relação de dependência tem duas implicações sobre a forma de trabalho proposta pelo PCA naquilo que se refere à identificação das potencialidades:

a) de um lado, o risco das potencialidades locais serem mascaradas pela dinâmica econômica do centro, de forma a só se poder analisar o desenvolvimento local como função do desenvolvimento central, matando as soluções que possam ser construídas mais à margem; e

b) de outro lado, o risco de serem desprezados os efeitos da dinâmica do centro sobre a economia local, interpretando-as como imunes a tais mudanças.

Mais uma vez, a superação desta dificuldade metodológica passa pela diminuição dos espaços de análise, garantindo ao analista e, em etapa posterior, àqueles que pretendem atuar sobre a realidade local, um maior controle sobre as variáveis do desenvolvimento. Em outras palavras: nessas localidades é mais pertinente identificar as potencialidades econômicas de uma localidade menor e de influência mais restrita, que fazer este estudo para uma realidade muito mais complexa.

A superação desses dois desafios, um de caráter mais político e outro de cunho metodológico, deve ser tarefa prioritária nas discussões sobre os rumos do PCA e para quaisquer iniciativas que estejam orientadas a difundir processos de desenvolvimento sustentável em localidades que apresentem características assemelhadas aos assentamentos humanos recentes aqui descritos. A título de sugestão, algumas propostas poderiam ser consideradas:

a) Conhecer melhor a comunidade:

As ações de mobilização da comunidade, identificação de lideranças e divulgação do processo que se pretende iniciar demandam mais tempo do que o que foi possível dedicar a essas tarefas nesse piloto.

O tamanho dos municípios e suas complexas relações políticas, assim como o fato de serem recentes o crescimento e a ocupação do município, dificultam aos agentes responsáveis pela realização do programa a clara identificação das pessoas que melhor representem os interesses da comunidade. Ademais, o grande porte dos municípios dificulta uma rápida divulgação dos princípios do desenvolvimento sustentável junto à comunidade.

Neste sentido, é fundamental para o programa e, mais importante ainda nesses assentamentos humanos recentes, que haja maior tempo para se trabalhar o envolvimento e a preparação da comunidade para assumir seu papel como ator no processo do desenvolvimento local. 
b) Formação de lideranças:

Também é importante oferecer, antes mesmo de se iniciar as atividades de capacitação para o DLIS, atividades voltadas para a formação das lideranças locais. Embora de caráter focal, essas iniciativas podem auxiliar na formação de capital humano nas localidades, além de preparar essas pessoas para a atividade de gestão do desenvolvimento local que consumirão pelo menos três meses de trabalho conjunto.

c) Estudo de potencialidades:

Os estudos de potencialidades precisam, além de levar em conta as relações com a dinâmica de desenvolvimento do centro atrativo, estar elaborados antes de se iniciarem as discussões da comunidade sobre o rumo do seu desenvolvimento. Ampliar-se-ão as possibilidades de um plano de desenvolvimento mais orientado pelos princípios da integração e da sustentabilidade, se houver uma clara noção de onde se pretende chegar com o processo que se vai iniciar.

Ao indicar potencialidades e vantagens comparativas da localidade, de forma antecipada, o programa permite que os membros do Fórum discutam e validem, ou não, as avaliações dos consultores, e dá aos técnicos que conduzem o processo de capacitação e aos próprios participantes do Fórum um fio condutor para as discussões e diagnósticos que serão realizadas.

d) Microrregiões de desenvolvimento:

Além disto, há que se discutir o próprio conceito de local que se está trabalhando. Embora Franco (1999) reconheça, desde o início, que o município não é, necessariamente, igual ao local, por uma questão de lógica e facilidade, os Fóruns estão sendo estruturados tomando o município como o local, exceto no Distrito Federal, onde o local é a Região Administrativa.

Para os assentamentos humanos recentes (e talvez para cidadesdormitórios em geral) é prudente redimensionar o local, a partir de regiões de desenvolvimento mais homogênas, simplificando a ação de capacitação dos membros do Fórum e para gestão do processo de promoção do desenvolvimento local. Essas Microrregiões de Desenvolvimento Sustentável (MDS) seriam estabelecidas levando-se em consideração os seguintes aspectos:

- apresentarem uma dinâmica (história) comum no que se refere ao seu desenvolvimento;

- compartilharem dificuldades sócio-econômicas, garantindo um certo grau de homogeneidade nas suas carências e demandas; e

- mais importante, compartilharem uma ou um conjunto de potencialidades que tornem mais provável o deslanchar de uma dinâmica sustentável de desenvolvimento. 
Embora não sejam soluções suficientes para superar os desafios que a tarefa de estimular novas práticas e modelos de promoção do desenvolvimento, as idéias e considerações aqui colocadas podem servir para auxiliar o PCA, ou iniciativas assemelhadas, a organizar uma necessária intervenção nos municípios das regiões metropolitanas brasileiras.

\section{Notas}

1 A realização deste trabalho deve-se a todos os nossos parceiros no PCA (Ministério do Planejamento, Orçamento e Gestão, Comunidade Solidária, SEBRAE/DF, SEBRAE/GO, SEBRAE/MS, Organização Voluntários de Goiás, Secretaria de Solidariedade/DF, PROMOSUL/MS, Prefeituras Municipais, Administrações Regionais, Fundação João Pinheiro, Fundação Getúlio Vargas) e, principalmente, aos nossos companheiros no processo de capacitação: Mariza, Suzana, Zeca, Carmen, Marco Aurélio, Osmar e Edson.

2 Como se analisará com maior detalhe à frente, a racionalidade que norteou o processo de construção de Brasília e de ocupação territorial no Distrito Federal importou no surgimento freqüente de invasões, que assim eram consideradas uma vez que a terra era de propriedade do Estado. Essa mesma lógica de ocupação dos espaços também importava em ações constantes do GDF, visando à remoção dessas populações das áreas invadidas em um processo que foi denominado de erradicação.

3 O estudo de dos Anjos (1998), as cidades de Riacho Fundo, Brazlândia e Paranoá aparecem como envolvidas por vetores secundários de crescimento urbano consolidado, sendo que o vetor principal é o que partindo dos pólos principal e complementar, seguem a BR 040 (Brasília/Belo Horizonte) na direção do Novo Gama/GO.

4 O referido estudo aponta cinco localidades com essas caracterísitcas, que são: Novo Gama, Santo Antônio do Descoberto, Águas Lindas, Planaltina de Goiás e Formosa. Das cinco, só a última não esteve envolvida no PCA.

5 Segundo Paviani (1998), “As localidades periféricas, por não gerarem empregos condizentes com as respectivas populações, se constituem em núcleos-dormitórios e reserva de mão-de-obra. Perdem enormes contingentes de ativos em favor do Plano Piloto, ocasionando movimentos pendulares diários de grande monta, o que exige centenas de ônibus (que permanecem ociosos grande parte do dia). (...) Além de serem depósitos de mão-de-obra, as localidades periféricas são excluídas do mercado formal de trabalho por não possuírem atividades capazes de criar postos de trabalho."

6 Cidade-satélite ao sul da Ceilândia. Atualmente, conta com uma população de mais de 300.000 habitantes, sendo talvez o mais acabado modelo de assentamento humano recente na forma definida para este trabalho.

7 Um aspecto interessante a observar, que reforça esse absurdo crescimento da população de Águas Lindas, é o comportamento da população do município de Santo Antônio do Descoberto, do qual ele foi desmembrado. De acordo com a contagem da população do IBGE, a população de Santo Antônio, antes da emancipação de Águas Lindas era de 107.672 pessoas. Após o desmembramento, a população desse município caiu para 67.024. Segundo estimativas mais recentes, a população somada dos dois municípios está em aproximadamente 230.000 habitantes. 
8 Informações relativas à população de Brazlândia para os anos 1970/1980/1991 e 1995, extraídas da tabela 2.2 (p.p. 27) do Marco de Referência para o PLANRIDE.

9 Entre 1991 e 2000 a população do Distrito Federal saiu de aproximadamente 1,6 milhão para 2 milhões, ou um crescimento de cerca de $25 \%$ para o período.

10 Segundo Brandão, citado por Iwakami (1998), o maior acréscimo de moradores na Vila Paranoá se dá no período 1972/1974. Esse crescimento poderia ser explicado pela dificuldade dos "invasores" removidos para a Ceilândia e para satélites distantes (Planaltina e Brazlândia) de se adaptarem à nova realidade, retornando para o Paranoá.

11 Nesse movimento merece destaque a atuação da Associação dos Moradores da Vila Paranoá que, na segunda metade dos anos 80 , pressionou o GDF para a regularização e fixação da vila.

12 Os bairros do Lago Sul e Lago Norte são áreas residenciais com o mais alto nível de renda do Distrito Federal (bairros nobres), absorvendo boa parte da mão-de-obra do Paranoá, principalmente para serviços domésticos, de construção e pequenas reformas.

13 Dados extraídos do Levantamento das Potencialidades: Vocações e Vantagens Comparativas da Localidade de Planaltina de Goiás elaborado pelo consultor Mário Rodrigues Filho para o PRODER-Especial do SEBRAE.

$14 \mathrm{O}$ mesmo não se identifica com a mesma intensidade nos moradores das cidadessatélites uma vez que, como eles são moradores do Distrito Federal e não da localidade, tal sentimento é percebido em menor escala. Embora seja comum o sentimento de vergonha.

15 Neste aspecto específico, merece destaque o papel que os religiosos, especialmente os pastores evangélicos, assumem nesses assentamentos humanos recentes. Segundo observação do consultor do SEBRAE/GO que trabalhou no programa, no município do Novo Gama/GO, o número de estabelecimentos religiosos só encontrava comparação com o número de bares, superando qualquer outro tipo de atividade.

16 Segundo o autor, a posição social pode ser medida de diversas maneiras, a saber: sua renda; sua posição profissional; seu grau de instrução; seu nível de consumo; ou por algum índice composto por duas ou mais dessas variáveis. Ainda para Pizzorno, além desses índices tradicionais, é possível adotar outros, tais como: o tempo de residência em determinado local; a posição "sociométrica" em um determinado grupo de amigos ou sócios; sua posição hierárquica; e até mesmo a posição territorial.

${ }^{17}$ Uma ressalva há de ser feita no caso do Distrito Federal. Em função de atraso na seleção das localidades que participariam do programa, a Instituição Capacitadora, a Interlocução Estadual e a Administração Regional tiveram muito pouco tempo para realizar reuniões preparatórias para o lançamento. Entretanto, em cada localidade, foram realizadas pelo menos duas reuniões antes do lançamento do programa.

18 Em função do acelerado crescimento populacional dessas localidades, há grande conflito entre as informações demográficas. Assim, optou-se por adotar como referência para esta comparação, a população que os Fóruns de Desenvolvimento trabalharam para orientar suas discussões. Como se observa, são dados aproximados.

19 Fórmula de cálculo: (número de participantes x 1000)/população.

20 Não é pertinente fazer essa mesma comparação para o Distrito Federal, a não ser que se agregassem outras variáveis. Isto porque, independentemente da RA ou da Zona Eleitoral em que as pessoas estão cadastradas, todas são eleitoras do Distrito Federal.

${ }^{21}$ Embora emancipado em 1891, com a criação do Distrito Federal, o município de Planaltina de Goiás teve sua sede desapropriada, de tal maneira que a nova "cidade" de Planaltina é de 1970.

22 É importante destacar que todos esses municípios (assim como todo o estado de Goiás) sempre tiveram no setor primário o seu principal fator de desenvolvimento econômico, especialmente a pecuária extensiva. 
${ }^{23}$ Na versão para o Distrito Federal, que não possui municípios, os PMDR e CMDR previstos pelo PRONAF foram convertidos em PRDR e CRDR.

24 Citado em Planejando o Desenvolvimento Sustentável - A experiência recente no Nordeste do Brasil, IICA.

25 Para Pizzorno, os tipos de participação política poderiam ser classificados em quatro categorias, a saber: a já mencionada participação civil; o profissionalismo político, ou seja, o exercício da política como profissão e meio de vida; os movimentos sociais, que são ações onde a solidariedade política prevalece, mas que ocorrem fora do Estado; e o que ele chama de subcultura, que caracterizam-se por ações extra-estatais onde a solidariedade privada prevalece.

26 O IBRAD ofereceu certificado de participação do processo de capacitação a todos os membros dos Fóruns de Desenvolvimento com freqüência às reuniões promovidas, acima de $75 \%$.

27 É claro que esse raciocínio deixa de fora algumas variáveis que podem ter papel relevante na presença das pessoas nos eventos promovidos. Um caso emblemático é o do Paranoál DF, a localidade com pior desempenho. Ao notar que a evasão naquele Fórum estava muito acima das outras, a equipe do IBRAD tentou identificar as causas desse processo, e uma das causas mais freqüentemente apontadas era o fato de que, entre $1998 \mathrm{e}$ 1999, este era o quarto processo de diagnóstico e planejamento participativo pelo qual as localidades estava passando. Primeiro o PRDR do PRONAF, em seguida o PRODER do SEBRAE/DF, depois o Direcionamento Estratégico da Adminstração Regional (GDF) e, então, o PCA.

28 Tarefa assumida pelos técnicos do SEBRAE, no âmbito do Proder-Especial, que produz estudos sobre potencialidades e vantagens comparativas dos municípios beneficiados pelo programa.

29 Embora não dispondo de dados que comprovem esta hipótese, parece possível extrapolar a realidade encontrada nas cidades-dormitório do Distrito Federal e entorno para a maioria dos municípios-dormitório nas outras regiões metropolitanas brasileiras.

30 Nunca é demais lembrar que das oito localidades estudadas, cinco são municípios goianos localizados no entorno do DF e que, embora sejam extremamente dependentes do desenvolvimento do DF e que já tenha sido criada uma região metropolitana do DF, as ações articuladas entre o GDF, o Governo do Estado de Goiás e as Prefeituras dos Municípios do Entorno ainda estão mais no campo das propostas que da prática.

31 Tanto assim que o PCA previa que os municípios indicados para o programa não poderiam ter população acima de 50.000 habitantes. A seleção de localidades fora deste critério em Goiás e Distrito Federal, entretanto, foi de grande valia para se discutir as possibilidades e os limites da forma de atuação prevista para o programa.

\section{Referências bibliográficas}

Adm — Consultoria \& Projetos Ltda. (1999), Levantamento das Potencialidades: Vocações e vantagens comparativas da localidade do Novo Gama. Goiânia: SEBRAE/GO.

Agência de Desenvolvimento Sustentável de Planaltina de Goiás. (1999), Plano de Desenvolvimento Integrado e Sustentável de Planaltina de Goiás. Planaltina de Goiás/ GO. Mimeo. 
Cavalcanti, Clóvis. (1997), Meio ambiente, desenvolvimento sustentável e políticas públicas. São Paulo: Cortez Editora; Recife: Fundação Joaquim Nabuco.

Dos Ansos, Rafael S. (1998), Mapa Imagem Multitemporal do Distrito Federal do Brasil 1987/1998. Brasília.

Demo, Pedro. (1999), Participação é Conquista (4a Edição) São Paulo: Cortez Editora.

Fórum de Desenvolvimento Sustentável de Águas Lindas. (1999), Plano de Desenvolvimento Integrado e Sustentável de Águas Lindas. Águas Lindas/GO. Mimeo.

Fórumde Desenvolvimento Sustentável de Brazlândia. (1999), Plano de Desenvolvimento Integrado e Sustentável de Brazlândia. Brazlândia/DF.

Fórumde Desenvolvimento Sustentável de Novo Gama. (1999), Plano de Desenvolvimento Integrado e Sustentável de Novo Gama. Novo Gama/GO. Mimeo.

Fórum de Desenvolvimento Sustentável de Padre Bernardo. (1999), Plano de Desenvolvimento Integrado e Sustentável de Padre Bernardo. Padre Bernardo/GO. Mimeo.

Fórum de Desenvolvimento Sustentável de Paranoá. (1999), Plano de Desenvolvimento Integrado e Sustentável de Paranoá/DF. Paranoá/GO. Mimeo.

Fórum de Desenvolvimento Sustentável de Riacho Fundo, (1999), Plano de Desenvolvimento Integrado e Sustentável de Águas Lindas. Riacho Fundo/DF. Mimeo.

Fórum de Desenvolvimento Sustentável de Santo Antônio do Descoberto. (1999), Plano de Desenvolvimento Integrado e Sustentável de Santo Antônio do Descoberto. Santo Antônio do Descoberto/GO. Mimeo.

Franco, Augusto de. (1999), Por que precisamos de DLIS? Brasília. Mimeo.

IPEA/IBge/Unicamp . (1999), Caracterização e tendências da rede urbana do Brasil, v. Ie II. Campinas/SP: Universidade Estadual de Campinas/UNICAMP.

Iwakami, Luiza N. (1998), Vila Paranoá: a luta desigual pela posse da terra urbana. A Conquista da Cidade: Movimentos Populares em Brasília (2 Edição). Brasília: Editora Universidade de Brasília.

JARA,Carlos. (1998), A Sustentabilidade do Desenvolvimento Local: Desafios de um processo em construção. Brasília: Instituto Interamericano de Cooperação para a Agricultura (IICA): Recife: Secretaria de Planejamento do Estado de Pernambuco/Seplan.

. (1999), Para Edmundo: Mimeo. Quito: Instituto Interamericano de Cooperação para a Agricultura (IICA).

M iranda, Carlos; Guimarães Neto, Leonardo; Buarque, Sérgio; Araújo, Tânia B. Planejando o Desenvolvimento Sustentável: A experiência recente do Nordeste do Brasil. Brasília: IICA.

Paviani, Aldo. (1998), A Construção Injusta do espaço urbano, A Conquista da Cidade: Movimentos Populares em Brasília ( $2^{a}$ Edição). Brasília: Editora Universidade de Brasília.

Paviani, Aldo (org.). (1998), A Conquista da Cidade: Movimentos Populares em Brasília ( $2^{\mathrm{a}}$ Edição). Brasília: Editora Universidade de Brasília.

Pereira, Paulo de Araújo. (1999), Levantamento das Potencialidades: Vocações e vantagens comparativas da localidade de Padre Bernardo. Goiânia: SEBRAE/GO.

Pizzorno, Alessandro. (1975), Introducción al estudio de la participación política, Participación y cambio social en la problemática contemporánea. Buenos Aires: Ediciones Siap Planteos.

Proops, John et alli. (1997), Realizando um mundo sustentável e o papel do sistema político na consecução de uma economia sustentável. Meio ambiente, desenvolvimento sustentável e políticas públicas. São Paulo: Cortez Editora: Recife, Fundação Joaquim Nabuco.

Putnam, Robert. (1996), Comunidade e Democracia: a experiência da Itália Moderna. Rio de Janeiro: Editora Fundação Getúlio Vargas. 
Rodrigues Filho, Mario. (1999), Levantamento das Potencialidades: Vocações e vantagens comparativas da localidade de Planaltina de Goiás. Goiânia: SEBRAE/GO.

Secretaria de Políticas Regionais/SEPRE \& Instituto Interamericano de Cooperação para a A gricultura/IICA. Marco de Referência para o Plano Estratégico de Desenvolvimento do Distrito Federal e Entorno (PLANRIDE). (1998), Brasília/DF: SEPRE/IICA.

Tannús Junior, Humberto. (1999), Santo Antônio do Descoberto: Levantamento das Potencialidades Locais. Goiânia: SEBRAE/GO. 


\section{Participação e desenvolvimento em assentamentos humanos recentes \\ Paulo Henrique Lustosa}

O Programa Comunidade Ativa, do Governo Federal, foi objeto de uma série de ações de caráter experimental em todo o país, tendo como finalidade principal testar e delimitar um modelo de intervenção capaz de induzir processos de promoção do desenvolvimento local em bases sustentáveis.

Dentre os componentes do programa, a capacitação das comunidades para o planejamento participativo era ferramenta básica, tendo por finalidade organizar e envolver as populações dos municípios beneficiados neste processo.

$\mathrm{O}$ presente texto discute a experiência do IBRAD no processo de capacitação das comunidades do Distrito Federal e entorno goiano, bem como as dificuldades e restrições impostas à aplicação da metodologia e dos conceitos que fundamentam o programa, em função das especificidades desses assentamentos humanos recentes.

\section{Participación e desarollo en asentamientos humanos recientes \\ Paulo Henrique Lustosa}

El Programa Comunidad Activa del Gobierno Federal fue objeto de una serie de acciones de carácter experimental en todo el país, teniendo como finalidad principal probar y trazar un modelo de intervención factible de inducir procedimientos de promoción de desarrollo local en bases sustentables.

La capacitación de las comunidades para el planeamiento participativo era considerada herramienta básica, entre los componentes de dicho programa, teniendo como finalidad organizar e involucrar las poblaciones de los municipios beneficiados de este proceso.

El presente texto trata de la experiencia del IBRAD en el proceso de capacitación de las comunidades del Distrito Federal y alrededores goianos, así como las dificultades y restricciones impuestas a la aplicación de la metodología y de los conceptos que fundamentan el programa, en vista de las especificaciones de esos asentamientos humanos formados recientemente.

\section{Participation and development in recent human settlements \\ Paulo Henrique Lustosa}

The Brazilian Federal Government Programme Comunidade Ativa (Active Comunity) suffered a number of experimental types of actions countrywide. The main objective was to bring up and create intervention models capable of inducing processes of local development on sustainable basis.

Amongst all components, community capacity building of the communities for participative planning was the applied basic tool in order to organise and involve groups of all beneficiaries' counties.

This document brings about IBRAD's experience in the Federal District of Brazil as well as its surroundings areas. The consequent difficulties and restrictions that came up during methodology application are also discussed, not to mention the concept over which the programme was built as a result of these recent human settlements singularities.
Ano 51

Número 1

Jan-Mar 2000

Paulo Henrique

Lustosa é

administrador de empresas, mestrando em Política Social pela UnB e presidente do IBRAD 
A Revista do Serviço Público é uma publicação da ENAP Escola Nacional de Administração Pública, voltada para a divulgação e debate de temas relacionados ao Estado, à Administração Pública e à gestão governamental. Procurando o aprimoramento permanente da revista, tanto no seu conteúdo quanto na apresentação gráfica, pedimos aos nossos colaboradores a observação das normas abaixo descritas.

\section{Normas para os colaboradores}

1. Os artigos, sempre inéditos no Brasil, devem conter em torno de 25 laudas de 20 linhas de 70 toques.

2. Os originais devem ser encaminhados ao editor, em disquete, em programa de uso universal, com uma cópia impressa. Usar apenas as formatações-padrão.

3. Cada artigo deve vir acompanhado de um resumo analítico em português, espanhol e inglês, de cerca de 150 palavras, que permita uma visão global e antecipada do assunto tratado.

4. Na primeira página do artigo, deve constar informação sobre formação e vinculação institucional do autor (em até duas linhas).

5. Notas, referências e bibliografia devem vir ao final do artigo, e não ao pé da página. Notas e referências, sendo o caso, devem vir devidamente numeradas.

6. Além de artigos, a revista receberá comunicações, notas informativas, notícias e relatórios conclusivos de pesquisas em desenvolvimento, com até 15 laudas. Resenhas de livros, em torno de 4 laudas, devem conter uma apresentação sucinta da obra e eventuais comentários que situem o leitor na discussão.

7. Os trabalhos que se adequarem à linha temática da revista serão apreciados pelo conselho editorial, que decidirá sobre a publicação com base em pareceres de consultores ad hoc.

8. Os originais enviados à Revista do Serviço Público não serão devolvidos. A revista compromete-se a informar os autores sobre a publicação ou não de seus trabalhos.

\section{Convite a resenhadores}

A Revista do Serviço Público convida todos os interessados em remeter resenhas de trabalhos publicados no Brasil e no exterior sobre Estado, Administração Pública e gestão governamental.

As resenhas devem ser originais e não exceder a cinco laudas datilografadas em espaço duplo com 20 linhas de 70 toques, e devem apresentar de modo sucinto a obra, com comentários que situem o leitor na discussão apresentada.

As resenhas devem ser enviadas em português, sem notas de rodapé, contendo o título completo e subtítulo do livro, nome completo do autor, local de publicação, editora e ano de publicação, bem como uma breve informação sobre a formação e vinculação institucional do resenhador (em até duas linhas), acompanhadas do respectivo disquete.

\section{Nota aos editores}

Pedimos encaminhar à Revista do Serviço Público exemplares de livros publicados, a fim de serem resenhados. Os resenhadores interessados receberão cópias dos livros enviados. 